\title{
Living with Alligators: A Florida Reality 1
}

\author{
Elizabeth Swiman, Mark Hostetler, Martin Main, and Sarah Webb Miller²
}

Living in Florida, we have to share our space with a very large reptile, the American alligator (Alligator mississipiensis). Because of Florida's booming population growth, people and alligators are constantly forced to cross paths, increasing the chances of conflict. Knowing where alligators live, how they behave, and what you can do to avoid conflict with alligators is key to sharing space safely (Figure 1).

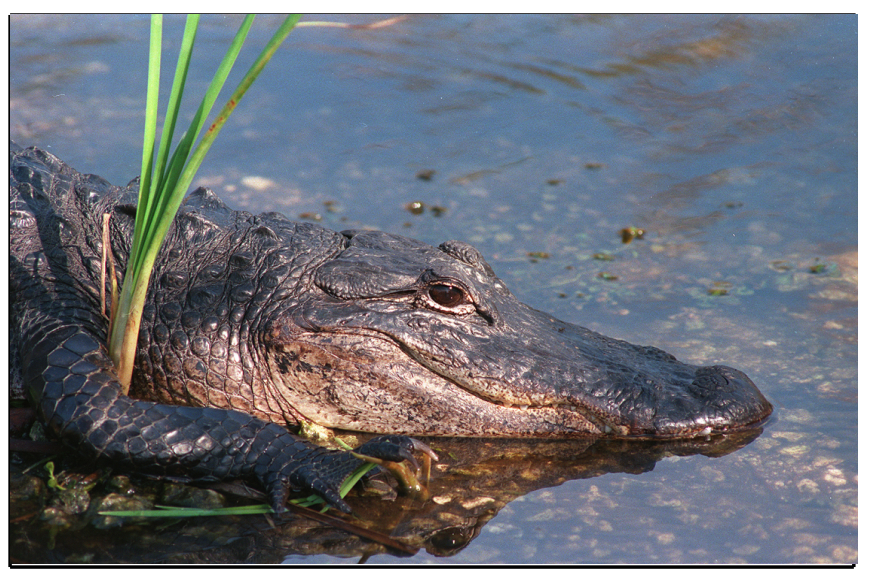

Figure 1. An American alligator. Credits: Photo by Milt Putnam.

\section{What is the natural history of alligators?}

The American alligator has survived the test of time. The family Alligatoridae first appeared about 35 million years ago. Today there are only two species of alligator in the world, the American alligator (Alligator mississippiensis) and the Chinese alligator (Alligator sinensis). The name "alligator" is widely believed to come from the Spanish name "el lagarto." This eventually was changed into "aligarto" and then "alligator" by English settlers.

In addition to the American alligator, the spectacled caiman (Caiman crocodilus) and the American crocodile (Crocodylus acutus) also occur in Florida. The family Alligatoridae includes five species of caimans, which are native to Central and South America. Spectacled caimans, which are smaller than the American alligator, have become established in some parts of south Florida, presumably from people releasing these pets into the wild. American crocodiles belong to the family Crocodilidae and are native to Florida. Whereas alligators prefer freshwater, crocodiles occur almost

1. This document is WEC 203, one of a series of the Department of Wildlife Ecology and Conservation, Florida Cooperative Extension Service, Institute of Food and Agricultural Sciences (IFAS), University of Florida. First published: September 2005. Please visit the UF/IFAS EDIS Web site at http://edis.ifas.ufl.edu for more publications.

2. Elizabeth Swiman, master's degree student; Mark Hostetler, associate professor and wildlife extension specialist; Sarah Webb Miller, wildlife extension program assistant; Dept. of Wildlife Ecology and Conservation; Martin Main, associate professor, Dept. of Wildlife Ecology and Conservation at Southwest Florida Research and Education Center, Immokalee; Florida Cooperative Extension Service; Institute of Food and Agricultural Sciences; University of Florida, Gainesville, Florida, 32611.

The Institute of Food and Agricultural Sciences (IFAS) is an Equal Opportunity Institution authorized to provide research, educational information and other services only to individuals and institutions that function with non-discrimination with respect to race, creed, color, religion, age, disability, sex, sexual orientation, marital status, national origin, political opinions or affiliations. U.S. Department of Agriculture, Cooperative Extension Service, University of Florida, IFAS, Florida A. \& M. University Cooperative Extension Program, and Boards of County Commissioners Cooperating. Larry Arrington, Dean 
exclusively in the marine and brackish coastal waters of extreme southern Florida. Crocodiles, which are an endangered species, are much less abundant and tend to be more secretive than alligators.

Consequently, conflicts are much more likely to occur between humans and alligators. Historically, alligators ranged from southern Virginia to the Florida Keys, west to the Rio Grande, and up to southern Oklahoma. Today, the American alligator can be found throughout the southeastern United States from the Carolinas to Texas and north to Arkansas (Figure 2). Large populations are found in Florida, southern Georgia, and Louisiana.

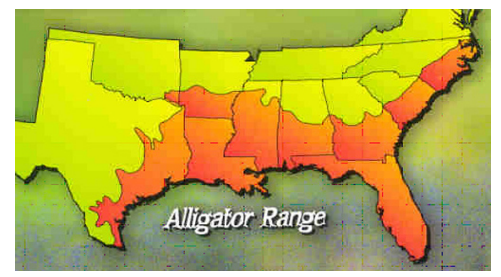

Figure 2. The range of the American alligator (where they occur) in the southeastern United States (see orange area, or darker shading, on map). Credits: Map courtesy of Florida Fish and Wildlife Conservation Commission.

Alligators may occur anywhere there is water-lakes, ponds, rivers, marshes, swamps, and even man-made canals. Although almost exclusively a freshwater species, they have been found in brackish water and marine (salt) waters. Alligators play important ecological roles both as top-level predators and because they often dig or wallow to create "gator holes" that hold water during dry periods. Sometimes gator holes are important features in the Everglades because they are often the only places where water is found during the dry season and provide critical habitat for fish and other wildlife. They also ensure the alligator will have a continued supply of food. Gator holes are so important that ecologists consider the alligator a "keystone species" because its actions provide habitat for many other species. In addition to gator holes, alligators sometimes dig dens in stream banks. Alligators may occupy dens year-round, but they are particularly important in winter and protect the alligator from the cold.

\section{What do alligators eat?}

Alligators primarily hunt at dusk or during the night. They lay motionless in wait for prey. Their prey selection seems to be determined primarily by size. An alligator's diet depends on what is available to it, which means it will eat just about anything including fish, frogs, birds, turtles, insects, snakes, small mammals, other alligators, white-tailed deer, wild hogs, and sometimes people's pets. Once the prey is caught, it is typically swallowed whole. Alligators have tremendously powerful jaws that can crush turtle shells and the bones of small mammals. A flap in their throat allows alligators to capture prey underwater without water entering their breathing passages.

When prey animals are too large to be swallowed whole (deer, wild hogs), the alligator will stash its kill underwater, pinning it under a submerged log or anywhere it can be wedged in for safe keeping. The alligator must then wait until the prey animal's hide is rotted and soft enough for the alligator to tear off chunks. Alligator teeth are designed for crushing and for a strong grip on prey. They are not sharp teeth like a bobcat or a wolf have for tearing meat.

\section{How does an alligator move?}

Alligators and all crocodilians have extensive modifications of the shoulder, pelvis and spine that enable them both to swim and to walk on land. In the water, alligators propel themselves through the water by moving their muscular tail from side to side (lateral undulations). Partially webbed feet also help push the alligator along through the water. Although crocodiles have been clocked swimming at $10 \mathrm{mph}$, there is no definitive answer for how fast an alligator can swim. When alligators walk on land, they can move very quickly and are capable of running at speeds of 7.5 to $9 \mathrm{mph}$ for short distances. The speed at which alligators can move makes them potentially dangerous in water and on land.

\section{How do alligators reproduce?}

Mating season for alligators occurs from mid-April through May. To attract females, males display by head-slapping the water and producing a deep rumbling bellow. Once a male-female pair is 
formed, they will swim together, touch each other's snouts, and blow bubbles. Mating takes place in the water and when completed, the male disperses and the female is left to search for a place to build her nest.

Female alligators construct nests by mounding up vegetation, sticks, leaves, and mud in a sheltered spot in or near water (Figure 3). Females use their whole bodies during nest construction-body and tail to clear an area, jaws to gather and drag vegetation, and hind legs to dig the hole in the mound for the eggs. After completing the nest, the female will deposit all of her eggs (ranging between 20 and 50) at once and cover them up with more vegetation for incubation. She may move vegetation around to keep the eggs at a fairly constant temperature. Females stay near the nest during incubation and actively defend it from predators like raccoons. Females will also be aggressive toward humans, often hissing and charging at intruders, so alligator nests should never be approached.

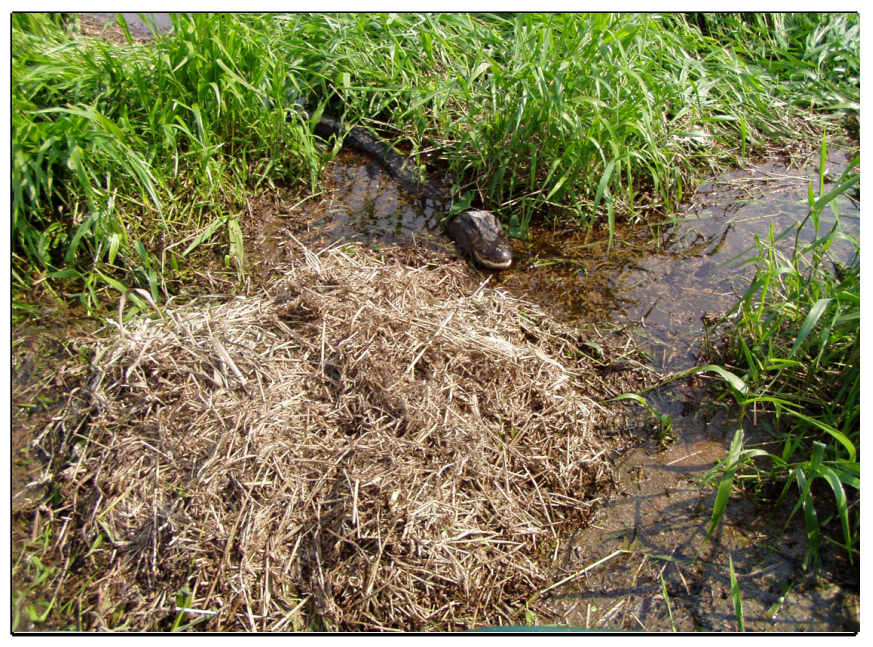

Figure 3. An American alligator nest (the mound of dried grass). See the mother alligator guarding the nest? (She's at the upper right side of the nest.) Credits: Photo by Amanda Rice.

Alligator eggs incubate for about 65 days. During this time, the alligator embryos develop and the sex is determined by the temperature at which the eggs were incubated (temperature-dependent sex determination). A temperature of $30^{\circ} \mathrm{C}\left(86^{\circ} \mathrm{F}\right)$ or below produces females, and a temperature of $33^{\circ} \mathrm{C}$ $\left(91.4^{\circ} \mathrm{F}\right)$ or higher produces males. In between those temperatures, at $32^{\circ} \mathrm{C}\left(89.6^{\circ} \mathrm{F}\right)$, there is about a $50-50 \%$ chance of getting males or females.
Once incubation is complete and the hatchlings (Figure 4) are ready to emerge from their eggs, they emit a "yerping" sound. A few hatchlings yerping stimulates the other hatchlings in the clutch to yerp. This signals the female that the eggs are about to hatch, and she carefully opens the nest. The hatchlings tear through their leathery eggs with an egg tooth on the tip of their snouts, which falls off after a few days. The mother alligator can also help the hatchlings emerge by rolling eggs between her tongue and palate. This helps to assure that all the eggs hatch at the same time.

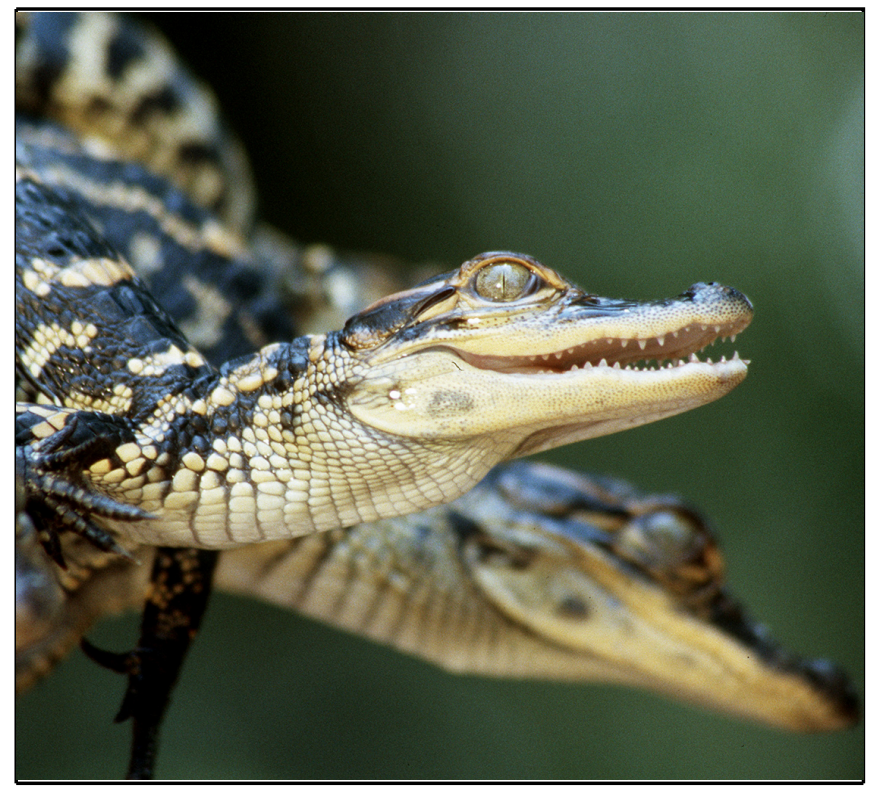

Figure 4. American alligator hatchlings (babies). The yellow striping is temporary camouflage for blending in with marsh grasses and rays of sunlight slanting through the grasses. Hatchlings emerge from their eggs in August and September in Florida, and often stay near the nest site for a couple of years. Hatchlings are usually 6-8 inches long. Credits: Photo by Thomas Wright.

\section{How can I stay safe around alligators?}

Alligators and Floridians usually have a peaceful coexistence, but there are recorded attacks and occasional fatalities. The key to staying safe is being alert to the possibility of alligators being present.

Never feed gators or swim or wade in waters where large alligators are likely or known to occur, especially at dusk or night (when they naturally feed). It is illegal to feed alligators. When humans feed alligators, it causes the alligators to lose their natural fear of humans and to associate humans with food. It doesn't matter if people feed them human-food like 
marshmallows or throw them fish guts when cleaning fish, it's all bad. It changes the alligator's behavior.

Normally, alligators avoid humans, but alligators that have been fed by humans will move toward humans and can become aggressive. Alligators that have been fed by humans are dangerous and should be reported to the Florida Fish and Wildlife Conservation Commission.

It's very important to keep children and pets away from the water's edge wherever alligators are likely to be present. Do not allow dogs to swim or explore waters that are known to have alligators because dogs look like prey to alligators. There are far more alligator attacks on dogs than on humans. An alligator's prey selection seems based mostly on size of the potential prey animal, not so much on a keen recognition of specific animals as prey or non-prey.

\section{What are some laws protecting alligators?}

The U.S. Fish and Wildlife Service (USFWS) lists alligators as a species threatened due to similarity of appearance, which specifically refers to the similarity between alligators and the endangered American crocodile. In Florida, alligators are considered a Species of Special Concern, but can be harvested legally under proper licenses and permits issued by the Florida Fish and Wildlife Conservation Commission. It is illegal to feed or harass alligators in Florida.

\section{What do I do if there is a nuisance alligator in my neighborhood?}

The best thing you can do is to contact your local or regional Florida Fish and Wildlife Conservation Commission (FWC) office or call

1-800-FWC-GATOR. If the alligator is deemed to be a threat to the public, a licensed trapper will be sent to remove it.

\section{What are some common misconceptions about alligators?}

\section{Myth \#1. You should run zigzag if you come across an alligator.}

This is a common misconception. First, it is rare for an alligator to pursue a human because humans are too large to be suitable prey. However, if an alligator does make an aggressive charge, run fast and straight (away from the alligator, of course). They usually do not run very far. But remember they are most likely to charge at you if you are near their nest.

\section{Myth \#2. Alligators have poor eyesight.}

Alligators actually have very good eyesight, which is an important adaptation for hunting. They are especially adapted to see and sense movement of potential prey animals. The position of their eyes on their head (almost on the side) gives them a wide sight range. The only place they cannot see is right behind them.

\section{Myth \#3. Alligators are not good climbers.}

Alligators have sharp claws and powerful tails to help them push their bodies up. Young alligators are agile climbers and adults have been known to climb fences to get to water or escape captivity. Low fences, therefore, may not be sufficient protection for pets in areas where alligators are present. Fences should be more than 4.5 feet tall if you are attempting to keep alligators out of your yard.

\section{Myth \#4. Alligators make good pets.}

This is entirely untrue. Alligators make terrible pets. Although baby alligators may seem like a cool pet, it is illegal to possess or take an alligator without the proper licenses and permits from the Florida Fish and Wildlife Conservation Commission. Alligators are purely instinctual hunters and do not show affection. Unlike cats and dogs, alligators will never love the hand that feeds them.

\section{Additional Information}

\footnotetext{
- Crocodile Specialist Group-Crocodilians

Natural History and Conservation:

http://www.flmnh.ufl.edu/cnhc
} 
- Florida Fish and Wildlife Conservation

Commission: http://www.floridaconservation.org

- Living with Alligators:

http://wildflorida.org/gators/faq/lwa.htm

- Alligators:

http://www.myfwc.com/critters//alligators.asp

- Alligators and Crocodiles -- Quick Reference

Sheet, Cooperative Extension Publication

WEC-QRS-003, UF/IFAS Dept of Wildlife

Ecology and Conservation:

http://edis.ifas.ufl.edu/UW003

- American Crocodiles (Crocodylus acutus) in Florida, Cooperative Extension Publication WEC 38, UF/IFAS Dept. of Wildlife Ecology and Conservation: http://edis.ifas.ufl.edu/UW157

- More publications from the University of Florida about the alligator farming industry at http://edis.ifas.ufl.edu, search with keyword "alligator" to see all alligator-related publications. 